\title{
Surface Properties of Dental Polymers: Measurements of Contact Angles, Roughness and Fluoride Release
}

\author{
Fátima Namen ${ }^{\mathrm{a} *}$, João Galan Jr. ${ }^{\mathrm{b}}$,José Farias de Oliveirac ${ }^{\mathrm{c}}$, Rodrigo Derossi Cabreira ${ }^{\mathrm{a}}$, \\ Fernando Costa e Silva Filho , Alex Balduino Souza ${ }^{\mathrm{b}}$, Gustavo de Deus ${ }^{\mathrm{b}}$ \\ anstituto de Biofísica Carlos Chagas Filho, CCS, Bloco G, \\ Universidade Federal do Rio de Janeiro - UFRJ, \\ Ilha do Fundão, 21949-900 Rio de Janeiro - RJ, Brazil \\ ${ }^{\mathrm{b}}$ Universidade Veiga de Almeida - UVA, \\ Rua Ibituruna, 108, Tijuca, 20271-901 Rio de Janeiro - RJ, Brazil \\ 'Programa de Pós Graduação em Metalurgia e Ciência dos Materiais, \\ Centro de Tecnologia, COPPE, Universidade Federal do Rio de Janeiro - UFRJ, \\ Ilha do Fundão, CP 68501, 21945-970 Rio de Janeiro - RJ, Brazil
}

Received: January 28, 2007; Revised: August 11, 2008

\begin{abstract}
Objective: Earlier studies on some dental materials measured roughness and/or contact angles or fluoride release separately. In the present study, five dental polymers were investigated to ascertain their contact angles, wettability, roughness, and fluoride release in dry or wet conditions. Methods: Samples for 5 materials were prepared and stored dry or wet in deionized water $\mathrm{pH}$ 6.8. Samples were submitted to finishing/polishing procedures, and the measurements in Goniometer, roughness $(\mu \mathrm{m})$ and fluoride analysis Results and conclusions: Except for the Ariston pHc, all the materials displayed high contact angles when measured with water, showing hydrophobic characteristics. Roughness changed the contact angles, especially those of Ariston $(\alpha<0.05)$. Fluoride did not modify the contact angles, but increased the roughness of the finished material.
\end{abstract}

Keywords: dental polymers, surface roughness, surface hydrophobicity, release of fluoride

\section{Introduction}

Aesthetic restorative materials of composite resins regularly used in dentistry are composed of polymers to which inorganic particles are usually associated ${ }^{1-5}$. These polymers, mainly BIS-GMA ${ }^{6}$, exhibit several particular characteristics such as the release of residual monomers, microporosity and cracking, etc ${ }^{7-9}$. All these characteristics seem to be related to surface finishing treatments, particularly those carried out in dental clinics ${ }^{10-12}$. In addition, it has been pointed out that either ormocers (organically modified ceramics) or compomers (polyacid-modified resin composites) may be sources of released fluoride particles ${ }^{13-15}$.

Composite dental restorative materials can be modified mechanically by brushing, polishing, abrasion, erosion and microcracking processes, or chemically through an acid medium ${ }^{16-19}$. Hydrophobicity, an important characteristic of hard composites, affects the initial water absorption and the adhesion of oral bacteria. Changing the hydrophobicity of the dental polymer surfaces can also affect the adhesion of oral bacteria ${ }^{20-23,27}$.

The breakdown of the marginal areas between enamel and restorative material can provide potential pathways for bacterial reinfection and recurrence of caries. Like other hard surfaces used in dental restorations, restorative materials are covered with an organic biofilm, which usually consists of host and bacterial elements. Different chemical properties and surface topographies of the various materials may play a role in biofilm formation and influence the differences in composition and general properties from one to another ${ }^{24-26}$.

Several studies have found that the fluoride added to materials can alter wettability and plaque formation, as well as the adherence of Streptococcus mutans ${ }^{27-30}$. However, other authors contend that the presence of fluoride on dental materials does not modify the materials' basic characteristics ${ }^{31,32}$.
The measuring of contact angles at the solid-air-liquid meeting point is a widely known technique used to investigate the wettability of solid surfaces ${ }^{33}$. The values obtained depend on the kind of surface topography, surface tension of the liquid and surface energy of the solid substrate ${ }^{33,34}$. Thus, the relative wetting characteristics of a liquid-solid interface can be inferred by contact angle measurements. It has been shown that the contact angle on a solid surface decreases as the surface becomes rougher ${ }^{38-35}$. As mentioned earlier, finishing and polishing procedures may result in differences in the surface roughness of dental materials, thus possibly affecting the formation and adhesion of bacterial plaques ${ }^{33}$. Another point that should be considered with regard to wettability is the presence of fluoride filler particles. According to previous reports ${ }^{36}$, the release of fluoride affects the wettability of restorative materials.

The present study involved an investigation of the influence of finishing treatments on the basic surfaces properties of several polymers commonly used in dental restorations.

\section{Materials and Methods}

\subsection{Dental polymers}

\subsubsection{Sample preparation}

All the samples were prepared according to the manufacturers' instructions in a $10 \mathrm{~mm}$ diameter, $2 \mathrm{~mm}$ high circular matrix (Table 1). The materials were photoactivated using a curing unit (Gnatus ${ }^{\circledR}$; Optilux 600, SP, Brazil) at $450 \mathrm{~mW} \cdot \mathrm{cm}^{-2}$. Both sides of the samples of all the materials were photoactivated for 40 seconds. The materials inserted into the circular matrix were placed on glass slides in 
three increments, using a Centrix syringe. The glass ionomer cement $\left(\mathrm{ChemFlex}^{\circledR}\right)$ was proportioned (50\% powder $/ 50 \%$ liquid) and handled according to the manufacturer's instructions before it was inserted into the matrix. The photocured resins were removed after polymerization and the ionomer removed after 15 minutes.

The samples were then subjected to the following surface treatments: Half samples were finished and polished and others half not. A group was stored in deionized water for 7 days ( $\mathrm{pH}$ 6.8) while the other group were stored dry in a plastic container at $37{ }^{\circ} \mathrm{C}$. Dental enamel from the extracted included molars was employed as the control. A total of 70 samples were tested (Group 1 - unpolished and unfinished samples and Group 2 - finished and polished samples. Both groups were stored wet and or dry).

The surfaces of the finished and polished samples were ground with 400, 500 and 800 grit silicon carbide sandpaper (Struers A/S, Copenhagen, Denmark), water cooled, and polished with fine-grained abrasive paste (Proxy; Ivoclar/Vivadent, Liechtenstein). Before tests all the samples were washed with deionized water; half were stored wet and other half stored dry for the experiments.

\subsubsection{Measurement of contact angles}

The contact angles were measured on one side of the samples. Briefly, the samples were placed in a Contact Angle Goniometer (Rame-Hart Inc., Mountain Lakes NJ, USA) attached to an Image Analyzer (Rame-Hart Inc., Mountain Lakes NJ, USA) and the measurements were done with either water or glycerol. Each sample was subjected to 10 measurements in each 4-angle position: vertical left, vertical right, horizontal left and horizontal right. A total of 1,760 measurements were taken.

\subsubsection{Roughness determination}

The surface roughness $(\mu \mathrm{m})$ was determined at 10 different points on all the samples, using a Surftest 211 profilometer (Mitutoyo, Japan).

\subsubsection{Fluoride release}

After storage for 7 days at $\mathrm{pH} 6.8$ in $5 \mathrm{~mL}$ deionized water, the samples were analyzed in a potentiometer (Corning Model 125/2, USA) with a specific fluoride electrode, with the solution adjusted using $2.0 \mathrm{~mL}$ of TISAB II (Corning, USA).

\subsubsection{Statistical analysis}

The contact angle and surface roughness measurement data were analyzed by ANOVA and multiple comparisons were made using the Bonferroni test $(\alpha=0.05)$.

\section{Results}

\subsection{Surface wettability}

The contact angle $(\theta)$ of the dry or wet samples of dental material formed by drops of water or glycerol were measured, as indicated in Tables 2 and 3 . The mean $\theta$ values differed between wet and dry samples. Unfinished samples showed similar water and glycerol drop contact angles (Table 2; left-hand side). However, the wettability of finished samples was very dissimilar. Water drops in contact with the surfaces of finished samples of Solitaire 2 or Tetric Ceram ${ }^{\circledR}$ showed higher $\theta$ values $\left(81.2^{\circ}\right.$ and $79^{\circ}$, respectively) than the surfaces of ChemFlex $^{\circledR}\left(73.5^{\circ}\right)$, TPH $\left(71.3^{\circ}\right)$ and Ariston ${ }^{\circledR}\left(59.4^{\circ}\right)$ samples. The latter material displayed the lowest water drop $\theta$ (Table 2; left-hand side). Glycerol drops, in contrast, showed similar $\theta$ values varying from $82.2^{\circ}$ (Ariston $^{\circledR}$ ) to $89.3^{\circ}$ (Tetric Ceram $^{\circledR}$ ).

The contact angles of the wet surfaces of samples of each of the aforementioned dental materials were also evaluated with water or glycerol drops. As indicated in Table 3, the wettability data before and after finishing treatments were different. Water drops in contact with unfinished surfaces produced contact angles varying from $69.7^{\circ}$ (Ariston ${ }^{\circledR}$ ) to $88.0^{\circ}$ (Tetric Ceram ${ }^{\circledR}$ ). Similarly to dry surfaces, the finishing treatment did not alter the wettability of wet surfaces.

Table 1. Manufacturers and basic composition of the materials.

\begin{tabular}{|c|c|c|c|}
\hline Materials & Manufacturers & Basic composition & Batch number \\
\hline Solitaire 2 & Hereaus-Kulzer Germany & $\mathrm{BaAlF}$ polyglass and porous $\mathrm{SiO}_{2}$ monomers & DO154020 L9 \\
\hline Ariston $^{\circledast} \mathrm{pHc}$ & Ivoclar/Vivadent Liechtenstein & $\begin{array}{l}\text { Dimethacrylate, Ba Fluorsilicate glass, } \mathrm{SiO}_{2} \text {, } \\
\text { ytterbium trifluoride }\end{array}$ & A09633 \\
\hline Tetric Ceram $^{\circledR}$ & Ivoclar/Vivadent Liechtenstein & $\begin{array}{l}\text { Bis-GMA, Urethane dimethacrylate tri ethylene glycol, } \\
\mathrm{Al}, \mathrm{Ba} \text { Fluorsilicate, } \mathrm{SiO}_{2}\end{array}$ & E12544 \\
\hline ChemFlex $^{\circledR}$ & $\begin{array}{l}\text { Dentsply/DeTrey } \\
\text { Milford, DE, USA }\end{array}$ & $\begin{array}{l}\text { Glass ionomer cement, Fluoride Aluminum silicate, } \\
\text { Polyacrylic acid }\end{array}$ & 9805000607 \\
\hline $\mathrm{TPH}$ & $\begin{array}{l}\text { Dentsply/DeTrey } \\
\text { Milford, DE, USA }\end{array}$ & $\begin{array}{l}\text { Bis-GMA, Modified Urethane, } \\
\text { Bore Aluminum Silicate, } \mathrm{SiO}_{2}\end{array}$ & 58790 \\
\hline
\end{tabular}

Table 2. Contact angles (degrees ${ }^{\circ}$ ) and standard deviation at the air-liquid-solid interface of dry dental materials before and after surface finishing treatment.

\begin{tabular}{lcccc}
\hline \multirow{2}{*}{ Materials } & \multicolumn{2}{c}{ Finished } & \multicolumn{2}{c}{ Unfinished } \\
\cline { 2 - 5 } & Water & Glycerol & Water & Glycerol \\
\hline Solitaire 2 & $81.2(3.0)^{\mathrm{h}}$ & $83.9(3.5)^{\mathrm{a}}$ & $75.3(1.6)^{\mathrm{c}}$ & $75.8(2.0)^{\mathrm{e}}$ \\
Ariston $^{\circledR}$ & $59.4(3.7)^{\mathrm{i}}$ & $82.1(3.5)^{\mathrm{a}}$ & $78.0(2.6)^{\mathrm{d}}$ & $74.7(3.3)^{\mathrm{e}, \mathrm{f}}$ \\
Tetric Ceram $^{\circledR}$ & $79.0(1.7)^{\mathrm{j}}$ & $89.3(3.6)^{\mathrm{b}}$ & $75.8(3.9)^{\mathrm{c}, \mathrm{d}}$ & $79.3(4.7)^{\mathrm{g}}$ \\
Chemflex $^{\circledR}$ & $73.4(2.3)^{\mathrm{k}}$ & $87.8(3.3)^{\mathrm{m}}$ & $70.6(3.9)^{\mathrm{n}}$ & $79.3(3.9)^{\mathrm{g}}$ \\
TPH & $71.3(2.9)^{\mathrm{l}}$ & $87.5(4.7)^{\mathrm{b}}$ & $72.6(2.8)^{\mathrm{o}}$ & $72.5(3.9)^{\mathrm{f}}$ \\
\hline
\end{tabular}

A statistical analysis was carried out using ANOVA and the Bonferroni test. (Same letters in a column mean non-significant differences, while different letters indicate statistical differences). 
Table 3. Contact angles (degrees ${ }^{\circ}$ ) and standard deviation at the air-liquid-solid interface of wet dental materials before and after surface finishing treatment

\begin{tabular}{lcccc}
\hline \multirow{2}{*}{ Materials } & \multicolumn{2}{c}{ Finished } & \multicolumn{2}{c}{ Unfinished } \\
\cline { 2 - 5 } & Water & Glycerol & Water & Glycerol \\
\hline Solitaire 2 & $64.9(5.9)^{\mathrm{a}}$ & $72.8(5.5)^{\mathrm{f}}$ & $72.0(3.3)^{\mathrm{i}}$ & $75.1(4.3)^{\mathrm{n}}$ \\
Ariston $^{\circledR}$ & $57.8(3.8)^{\mathrm{e}}$ & $68.9(5.6)^{\mathrm{c}}$ & $69.6(3.9)^{\mathrm{j}}$ & $66.9(4.1)^{\mathrm{o}}$ \\
Tetric Ceram $^{\circledR}$ & $79.4(6.0)^{\mathrm{b}}$ & $85.4(4.8)^{\mathrm{g}}$ & $87.9(2.7)^{\mathrm{k}}$ & $82.2(3.9)^{\mathrm{p}}$ \\
Chemflex $^{\circledR}$ & $67.0(6.6)^{\mathrm{a}}$ & $68.2(4.4)^{\mathrm{c}}$ & $62.1(6.0)^{\mathrm{l}}$ & $72.0(5.9)^{\mathrm{d}}$ \\
TPH & $79.1(4.8)^{\mathrm{b}}$ & $79.2(9.3)^{\mathrm{h}}$ & $81.8(5.7)^{\mathrm{m}}$ & $70.2(4.3)^{\mathrm{d}}$ \\
\hline
\end{tabular}

A statistical analysis was carried out using ANOVA and the Bonferroni test. (Same letters in a column mean non-significant differences, while different letters indicate statistical differences).

The data in Table 3 (right side) indicate that the finishing treatment further changed the wettability of the samples when measurements were taken using water drops. The resulting angles varied from $57.8^{\circ}$ $\left(\right.$ Ariston $^{\circledR}$ ) to $79.4^{\circ}$ (Tetric Ceram $^{\circledR}$ ) and $79.2^{\circ}$ (TPH). Table 4 shows the contact angles (degrees) and standard deviation of the dental enamel surfaces in dry and wet conditions. As can be seen, there is no significant difference between water and glycerol in dry or wet conditions $(\alpha>0.05)$.

\subsection{Surface roughness}

Table 5 summarizes the surface roughness measurements $(\mu \mathrm{m})$. The Ra values of the finished surfaces were higher than those of the unfinished ones.

\subsection{Fluoride release}

Figure 1 shows the data on fluoride released from finished and unfinished samples. The finishing procedure affected fluoride release from Ariston samples.

\section{Discussion}

The contact angle measurement method is probably the most definitive way to determine the hydrophobicity of material surfaces. The angle is very high for water if the substrate is hydrophobic. When the surface is hydrophilic, the droplet quickly dissipates and the measured angle is low. Like other methods, the contact angle method gives an average value for hydrophobicity ${ }^{37}$. Contact angles change with surface topography, surface tension of the liquid, surface energy of the substrate, and level of interaction between the liquid and solid ${ }^{34,38-41}$.

Our results show that the materials tested here presented different surface characteristics such as composition, fillers, presence of fluoride particles, and topography. It appears that treating surfaces with polishing materials can alter their wettability. All the materials analyzed in this study showed high contact angles in the dry condition, especially the finished and polished samples, regardless of the liquid used for measuring (Table 2). The only exception was Ariston ${ }^{\circledR} \mathrm{pHc}$, which showed low values when measured with water $\left(59.41^{\circ}\right)$. This material tested in the unfinished condition yielded contact angle values of $78.02^{\circ}$, indicating that the material should not be finished.

The materials tested in the dry condition with both measurement liquids showed statistical differences $(\mathrm{p}<0.05)$ except for Solitaire and Ariston ${ }^{\circledR}$ (glycerol) and Tetric Ceram ${ }^{\circledR}$ and TPH (glycerol). It is possible that materials subjected to finishing procedures show similar superficial texture and surface energy. In similar conditions but without finishing, the materials showed more molecular interactions when tested with both water and glycerol. As Table 2 indicates, all the materials are hydrophobic in finished and unfinished conditions. The results of this study are partially compatible with previous find-
Table 4. Contact angles (degrees ${ }^{\circ}$ ) and standard deviation of the dental enamel surfaces.

\begin{tabular}{ccc}
\hline Conditions & \multicolumn{2}{c}{ Liquids } \\
\cline { 2 - 3 } & Water & Glycerol \\
\hline Dry & $83.7(8.68)^{\mathrm{a}}$ & $79.9(8.49)^{\mathrm{a}}$ \\
Wet & $67.3(9.56)^{\mathrm{b}}$ & $68.6(6.70)^{\mathrm{b}}$ \\
\hline
\end{tabular}

A statistical analysis was carried out using ANOVA and the Bonferroni test. (Same letters in a column mean non-significant differences, while different letters indicate statistical differences).

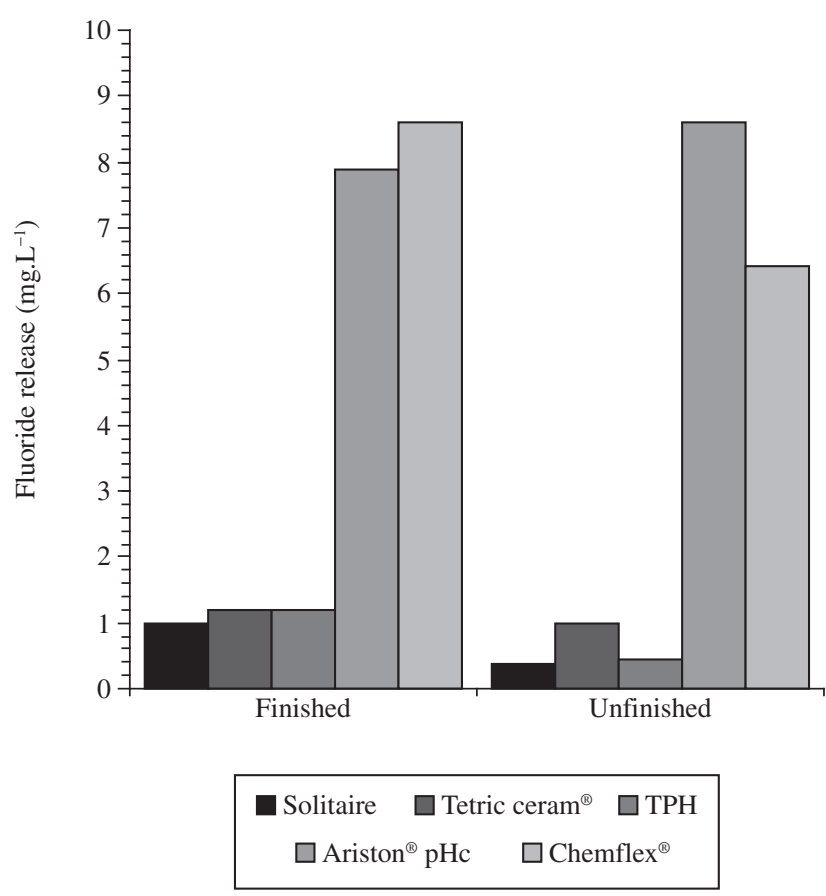

Figure 1. Fluoride released at $\mathrm{pH} 6.8$.

ings ${ }^{42}$ which stated that contact angles on solid surfaces decrease as the surface becomes rougher.

The formation of dental biofilms depends on the characteristics of the hard surface ${ }^{24}$.In the present study, we found that the dry condition and finishing procedures can also alter contact angles. The glass ionomer ChemFlex presented lower contact angles than the other materials (Table 1), indicating that this material has a tendency to absorb more saliva biofilms, which makes it more susceptible to the formation of dental plaque ${ }^{24}$,regardless of its fluoride content. Roughness is prob- 
Table 5. Mean values and standard deviation of surface roughness $(\mu \mathrm{m})$.

\begin{tabular}{lll}
\hline \multicolumn{1}{c}{ Materials } & Finished & Unfinished \\
\hline Solitaire 2 & $0.493(0.168)^{\mathrm{d}, \mathrm{e}, \mathrm{f}, \mathrm{g}, \mathrm{h}}$ & $0.204(0.105)^{\mathrm{a}, \mathrm{b}, \mathrm{c}}$ \\
Ariston $^{\circledR}$ & $0.434(0.083)^{\mathrm{g}, \mathrm{k}, \mathrm{n}, \mathrm{q}}$ & $0.184(0.026)^{\mathrm{b}, \mathrm{m}, \mathrm{p}}$ \\
Tetric Ceram $^{\circledR}$ & $0.449(0.087)^{\mathrm{h}, \mathrm{l}, \mathrm{o}, \mathrm{q}}$ & $0.140(0.062)^{\mathrm{c}, \mathrm{p}}$ \\
Chemflex $^{\circledR}$ & $0.912(0.276)^{\mathrm{r}}$ & $0.645(0.195)^{\mathrm{f}, \mathrm{j}}$ \\
TPH & $0.517(0.123)^{\mathrm{d}, \mathrm{i}, \mathrm{j}, \mathrm{k}, \mathrm{l}}$ & $0.369(0.081)^{\mathrm{a}, \mathrm{e}, \mathrm{i}, \mathrm{m}, \mathrm{n}, \mathrm{o}}$ \\
\hline
\end{tabular}

(Same letters in a column mean non-significant differences, while different letters indicate statistical differences).

ably a more significant factor than fluoride content, and the material has a tendency to be more hydrophilic than hydrophobic.

The mechanical and handling properties of dental composite resins depend on the concentration and particle size of the fillers. Proper finishing and polishing procedures are important to enhance the longevity of restored teeth. Previous studies have shown that finishing, surface roughness, surface integrity, and physicochemical properties of the restoration material can influence plaque retention ${ }^{13,15,26,48}$.

The mean values of 83.77 to 79.94 measured on dry enamel using water as the liquid medium showed very similar surface hydrophobicity to that obtained with dental polymers such as Tetric Ceram ${ }^{\circledR}$ and Solitaire 2.

A comparison of the superficial roughness $(\mu \mathrm{m})$ of the finished and unfinished materials revealed statistically significant differences $(\mathrm{p}<0.05)$ except between Ariston and Solitaire and between Ariston ${ }^{\circledR}$ and ChemFlex ${ }^{\circledR}$. However, no difference in roughness was found between finished and unfinished TPH. The results of this study are congruous with an earlier investigation ${ }^{11}$, which revealed significant differences in the roughness of dental materials subjected to different finishing procedures, with the lowest variability found in an ormocer material.

Several dental materials have fluoride incorporated into their matrices to improve the resistance of enamel and dentin to demineralization. However, the results have been conflicting insofar as clinical importance is concerned ${ }^{39}$.

\section{Conclusions}

Within the limitations of this study, the following conclusions were drawn:

1. All the finished and polished materials showed lower roughness values;

2. The Ariston $\mathrm{pHc}$ and Chemflex materials released larger amounts of fluoride than the other materials, and polishing altered their fluoride release; and

3. The polishing procedure changed the contact angle of the materials tested here.

\section{References}

1. Bowen R. Dental Filling material comprising vinyl silane treated fused silica and a binder consisting of the reaction product of bisphenol and glycidyl acrylate. Washington, USA; 1962. pat number 3,066,112.

2. Beun S, Glorieux T, Devaux J, Vreven J, Leloup G. Characterization of nanofilled compared to universal and microfilled composites. Dental Materials. 2007; 23(1):51-59.

3. Kawakami Y, Takeshige F, Hayashi M, Ebisu S. Fatigue of tooth-colored restoratives in aqueous environment. Dental Materials Journal. 2007; 26(1):1-6.

4. Stober T, Gilde H, Lenz P. Color stability of highly filled composite resin materials for facings. Dental Materials. 2001; 17(1):87-94.
5. Xu HH, Sun L, Weir MD, Takagi S, Chow LC, Hockey B. Effects of incorporating nanosized calcium phosphate particles on properties of whisker-reinforced dental composites. Journal Biomedical Materials Research B Applied Biomaterials. 2007; 81(1):116-125.

6. Roulet J. Degradation of Dental Polymers. USA: Karger Publ; 1987.

7. Mazzaoui SA, Burrow MF, Tyas MJ, Rooney FR, Capon RJ. Long-term quantification of the release of monomers from dental resin composites and a resin-modified glass ionomer cement. Journal Biomedical Materials Research. 2002; 63(3):299-305.

8. Ortengren U, Wellendorf H, Karlsson S, Ruyter IE. Water sorption and solubility of dental composites and identification of monomers released in an aqueous environment. Journal Oral Rehabilitation. 2001; 28(12):1106-1115.

9. Yap AU, Tan SH, Wee SS, Lee CW, Lim EL, Zeng KY. Chemical degradation of composite restoratives. Journal of Oral Rehabilitation. 2001; 28(11):1015-1121.

10. Almeida LR, Namen FM, Junior JG, Filho FCeS. Wettability of some dental aesthetic materials containing fluor after surface finishing treatments. Stoma. 2003; 68:5-11.

11. Ozgunaltay G, Yazici AR, Gorucu J. Effect of finishing and polishing procedures on the surface roughness of new tooth-coloured restoratives. Journal of Oral Rehabilitation. 2003; 30(2):218-224.

12. Yap AU, Mok BY. Surface finish of a new hybrid aesthetic restorative material. Operative Dentistry. 2002; 27(2):161-166.

13. Dummer PM, Harrison KA. In vitro plaque formation on commonly used dental materials. Journal of Oral Rehabilitation. 1982; 9(5):413-417.

14. Forsten L. Short- and long-term fluoride release from glass ionomers and other fluoride-containing filling materials in vitro. Scandinavian Journal of Dental Research. 1990; 98(2):179-185.

15. Svanberg M, Mjor IA, Orstavik D. Mutans streptococci in plaque from margins of amalgam, composite, and glass-ionomer restorations. Journal Dental Research. 1990; 69(3):861-864.

16. Attin T, Buchalla W, Hellwig E. Effect of topical fluoride application on toothbrushing abrasion of resin composites. Dental Materials. 2006; 22(4):308-313.

17. Kon M, Kakuta K, Ogura H. Effects of occlusal and brushing forces on wear of composite resins. Dental Materials Journal. 2006; 25(1):183-194.

18. Sadaghiani L, Wilson MA, Wilson NH. Effect of selected mouthwashes on the surface roughness of resin modified glass-ionomer restorative materials. Dental Materials. 2007; 23(3):325-334.

19. Senawongse P, Pongprueksa P. Surface roughness of nanofill and nanohybrid resin composites after polishing and brushing. Journal Esthetic and Restorative Dentistry. 2007; 19(5):265-273.

20. Olsson J, Carlen A, Holmberg K. Inhibition of Streptococcus mutans adherence by means of surface hydrophilization. Journal Dental Research. 1990; 69(9):1586-1591.

21. Rosenberg M, Judes H, Weiss E. Cell surface hydrophobicity of dental plaque microorganisms in situ. Infection and Immunity. 1983; 42(2):831-834. 
22. Nishitani Y, Yoshiyama M, Donnelly AM, Agee KA, Sword J, Tay FR, Pashley DH. Effects of resin hydrophilicity on dentin bond strength. Journal Dental Research. 2006; 85(11):1016-1021.

23. Polaquini SR, Svidzinski TI, Kemmelmeier C ,Gasparetto A. Effect of aqueous extract from Neem (Azadirachta indica A. Juss) on hydrophobicity, biofilm formation and adhesion in composite resin by Candida albicans. Archives of Oral Biology. 2006; 51(6):482-490.

24. Steinberg D. Studying plaque biofilms on various dental surfaces. In: Handbook of bacterial adhesion: Principles, methods and aplications. Totowa, NJ: Humana Press; 2000. p.353-369.

25. Al-Naimi OT, Itota T, Hobson RS, McCabe JF. Fluoride release for restorative materials and its effect on biofilm formation in natural saliva. Journal of Materials Science Materials in Medicine. 2007; 19(3):1243-1248. aug 15.

26. Beyth N, Bahir R, Matalon S, Domb AJ ,Weiss EI. Streptococcus mutans biofilm changes surface-topography of resin composites. Dental Materials. 2007; 24(6):732-736. sep 24.

27. Arai K, Kato K, Nakagaki H, Toyama A, Nagai N, Noguchi T, Kirkham J, Robinson C, Thuy TT ,Ha NT. Fluoride profiles in dental plaque in vivo formed on fluoride pre-treated human enamel. Caries Research. 2000; 34(3):254-259.

28. Samuel SM, Rubinstein C. Microhardness of enamel restored with fluoride and non-fluoride releasing dental materials. Braziian Dental Journal. 2001; 12(1):35-38.

29. Svanberg M, Krasse B, Ornerfeldt HO. Mutans streptococci in interproximal plaque from amalgam and glass ionomer restorations. Caries Research. 1990; 24(2):133-136.

30. Vogel GL, Zhang Z, Chow LC, Carey CM, Schumacher GE, Banting DW. Effect in vitro acidification on plaque fluid composition with and without a $\mathrm{NaF}$ or a controlled-release fluoride rinse. Journal of Denta Reseach. 2000; 79(4):983-990.

31. Attar N, Onen A. Fluoride release and uptake characteristics of aesthetic restorative materials. Journal of Oral Rehabilitation. 2002; 29(8):791-798.

32. Van Dijken J, Persson S, Sjostrom S. Presence of Streptococcus mutans and lactobacilli in saliva and on enamel, glass ionomer cement, and composite resin surfaces. Scandinavian Journal of Dental Desearch. 1991; 99(1):13-19.

33. Eick S, Glockmann E, Brandl B, Pfister W. Adherence of Streptococcus mutans to various restorative materials in a continuous flow system. Journal of Oral Rehabilitation. 2004; 31(3):278-285.

34. Rame E, Garoff S. Microscopic and macroscopic dynamic interface shapes and the interpretation of dynamic contact angles. Journal of Colloid and Interface Science. 1996; 177(1):234-244.
35. Silikas N, Kavvadia K, Eliades G, Watts D. Surface characterization of modern resin composites: a multitechnique approach. American Journal of Dentistry. 2005; 18(2):95-100.

36. Teughels W, Van-Assche N, Sliepen I, Quirynen M. Effect of material characteristics and/or surface topography on biofilm development. Clinical oral implants research. 2006; 17(2):68-81.

37. Doyle RJ. Contribution of the hydrophobic effect to microbial infection. Microbes and infection. 2000; 2(4):391-400.

38. Milleding P, Gerdes S, Holmberg K, Karlsson S. Surface energy of non-corroded and corroded dental ceramic materials before and after contact with salivary proteins. European Journal of Oral Sciences. 1999; 107(5):384-392.

39. Van Oss C. Hydrophobicity of biosurfaces - origin quantitative determination and interaction energies. Colloid Surface Biointerfaces. 1995; 5:91-110

40. Kwok DY, Neumann AW. Contact angle measurement and contact angle interpretation. Advances in Colloid and Interface Science. 1999; 81(3):167-249

41. Kwok DY, Neumann AW. Contact angle interpretation in terms of solid surface tension. Colloids and Surfaces A: Physicochemical and Engineering Aspects. 2000; 161(1):31-48.

42. Zisman W. Relation of the equilibrium contact angle to liquid and solid constitution. Advances in Chemistry Series. 1964; 43:1-51.

43. Godoy F. A new ion-releasing restorative material. American Journal of Dentistry. 1999; 12(S3)

44. Swift-Jr EJ. Effects of glass ionomers on recurrent caries. Operative Dentistry. 1989; 14(1):40-43.

45. Can-Karabulut DC, Batmaz I, Solak H, Tastekin M. Linear regression modeling to compare fluoride release profiles of various restorative materials. Dental Materials. 2007; 23(9):1057-1065.

46. Kavaloglu-Cildir S,Sandalli N. Compressive strength, surface roughness, fluoride release and recharge of four new fluoride-releasing fissure sealants. Dental Materials Journal. 2007; 26(3):335-341.

47. Li S, Hobson RS, Bai Y, Yan Z, Carrick TE, McCabe JF. A method for producing controlled fluoride release from an orthodontic bracket. European journal of orthodontics. 2007; 29(6):550-554. sep 4.

48. Liljemark WF, Bloomquist C. Human oral microbial ecology and dental caries and periodontal diseases. Critical Reviews in Oral Biology and Medicine. 1996; 7(2):180-198.

49. Schiffner U. Inhibition of enamel and root dentin demineralization by Ariston pHc: an artificial mouth study. American Journal of Dentistry. 1999; 12 Spec No (S10-12).

50. Kukletová M, Kuklová J, Christoforidis G. Ariston pHc restorative material.Clinical and morphological study. Scripta Medica (BRNO). 2003; 76(1):39-48. 
